\title{
Analysis of climate scenarios for Bolivia
}

\author{
Oscar Paz Rada*, Sergio Romero Crespo, Freddy Tejada Miranda \\ Ministerio de Desarrollo Sostenible y Planificación, Viceministerio de Desarrollo Sostenible y Medio Ambiente, \\ Dirección General de Medio Ambiente, Políticas y Normas, Programa Nacional de Cambios Climáticos, \\ Plaza España esq. Méndez Arcos No 710 , PO Box 1508, La Paz, Bolivia
}

\begin{abstract}
This paper presents a preliminary description of a study carried out in Bolivia to develop scenarios of climate change resulting from radiative forcing and produced by means of stabilized and transient General Circulation Models (GCMs). These models are valuable tools for simulating the physical processes which determine global climate. A variety of climates are present in Bolivia as a result of the country's physical characteristics, particularly altitude. The country is largely influenced by air masses from the north (Equatorial Amazon Current) and from the south (Austral Current). Therefore, to define a single and homogeneous scenario for the entire country is a particularly difficult task. Temperature and precipitation records from more than 20 weather stations located within the 3 main river basins of the country (Amazon Basin, 'Altiplano' Basin and Plata Basin) were graphically compared with GCM outputs under $1 \times \mathrm{CO}_{2}$ conditions. The GCMs used were GISS, UK89, CCCM and GFDL R30 . The models which best fit the actual values were identified in order to determine the expected temperature and precipitation variations under a doubled atmospheric carbon dioxide concentration condition $\left(2 \times \mathrm{CO}_{2}\right)$. In the case of Bolivia it was observed that the models providing the best fit were the GISS and the UK89, together with the GFDL $1 \%$ transient model; these were thus selected to develop the climate change scenarios describing possibie future trends in climate.
\end{abstract}

KEY WORDS: Bolivia $\cdot$ Climate $\cdot$ Climate Change $\cdot$ Climate scenarios $\cdot$ General Circulation Models

\section{INTRODUCTION}

Bolivia is located in the central part of South America, between $57^{\circ} 26^{\prime}$ and $69^{\circ} 38^{\prime} \mathrm{W}$ and between $09^{\circ} 38^{\prime}$ and $22^{\circ} 53^{\prime} \mathrm{S}$. It covers an area of approximately $1098000 \mathrm{~km}^{2}$ (Fig. 1).

The country is divided into 3 main geographic regions: the Andean region, the sub-Andean region and the valleys, and the region of the plains. The Andean region comprises a group of high arid plains which form the 'Altiplano' (plateau), flanked by the eastern and western cordilleras.

The mean annual precipitation in the Altiplano is $402 \mathrm{~mm}$ and the mean annual temperature is $11.02^{\circ} \mathrm{C}$. The mean annual precipitation and temperature values for the sub-Andean region and valleys are $496.1 \mathrm{~mm}$ and $16.3^{\circ} \mathrm{C}$ respectively. The values for the region of the plains - which is located at the foot of the western cordillera - are $1167 \mathrm{~mm}$ and $27.54^{\circ} \mathrm{C}$ respectively.

\footnotetext{
•E-mail: pncambio@clima.rds.org.bo
}

Each of these regions has its own characteristics as to atmospheric pressure, temperature, humidity and precipitation. Tropical, subtropical, temperate and cold areas are defined according to these characteristics. As a result of this, all climate types are present in Bolivia, which is therefore considered a unique 'microcosm'.

Climate varies as a function of altitude and is influenced by air masses from the north, i.e. the Corriente Ecuatorial Amazónica (Equatorial Amazon Current); and air masses from the south, i.e. the Corriente Austral (Southern Current).

The Bolivian Government has ratified the United Nations Framework Convention on Climate Change, by which countries are committed to developing and publishing national anthropogenic greenhouse gas emission inventories and mitigation plans. The Ministerio de Desarrollo Sostenible y Planificación, through the Dirección General de Medio Ambiente, Política y Normas and the Programa Nacional de Cambios Climáticos, is the executing agency for the Bolivia Climate Change Country Study, supported by the U.S. 


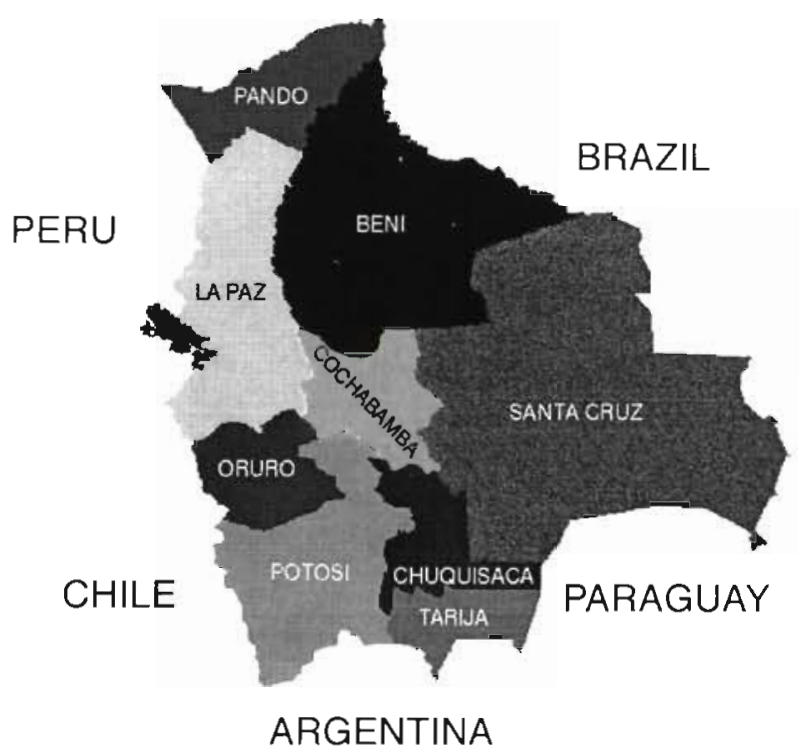

Fig. 1. Bolivia

Environmental Protection Agency (EPA). The goals of this study were to develop the 1990 greenhouse gas emissions inventory and to assess the degree of vulnerability of the sectors which are likely to be most impacted by climate change, thus affecting economic and social indices. The sectors addressed included agriculture, forests, livestock, and water resources. The study also sought to develop scenarios for the country that were as reliable as possible, both with regard to climate and to socioeconomic conditions, and to identify the most appropriate adaptation options for each sector under such scenarios.

This analysis, carried out within the framework of the above-mentioned Country Study, was an attempt to define climate change scenarios under the country's conditions on the basis of simulations with different models.

\section{METHODOLOGY}

The Grid Analysis and Display System (GrADS), developed at the Center for Land-Ocean-Atmosphere Interactions of the University of Maryland (USA) was applied for the analysis. The GrADS includes temperature, precipitation and solar radiation files for the following GCMs: GISS, GFDL R-30, UK89, CLIM and CCCM. All of these models were used in the study in order to identify the one which would best fit the observed data. A longitude-latitude point corresponding to the station or basin under study has to be specified in order to access the different model files. Since data are not available for all points of the globe, interpolation to the closest grid point is required.

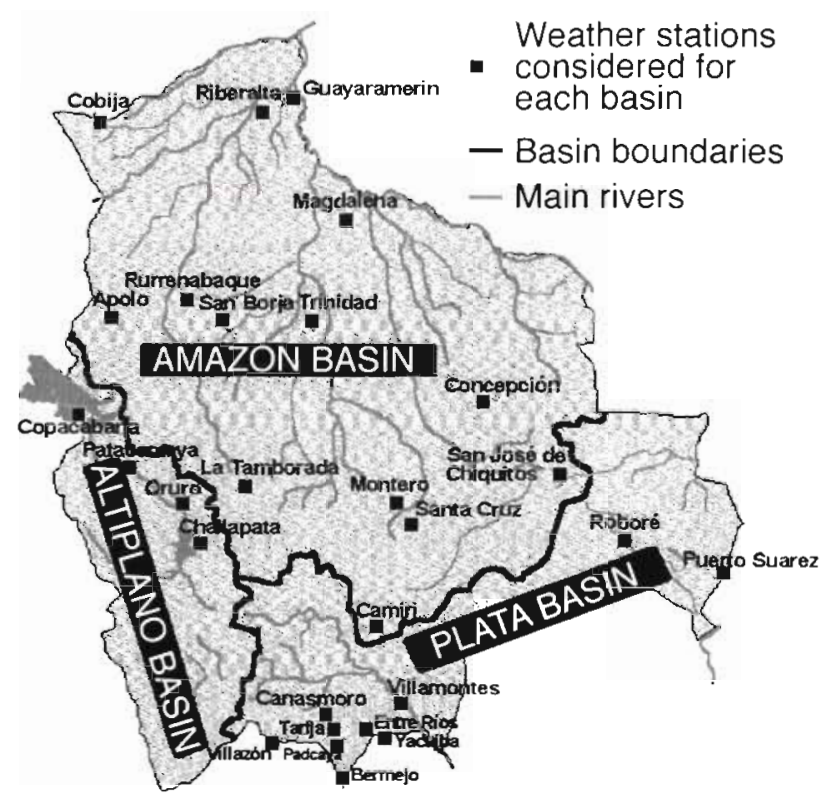

Fig. 2. Main Bolivian basins and location of weather stations

Climate data were obtained from a total of 28 weather stations located in the 3 main river basins in the country: the Amazon Basin, the Plata Basin and the Altiplano Basin. These basins comprise 10, 11 and 1 sub-basin respectively (Fig. 2).

Both temperature and precipitation data recorded at these stations, provided by the Servicio Nacional de Meteorología e Hidrología (SENAMHI 1995), were compared with those provided by the different models under the $1 \times \mathrm{CO}_{2}$ scenario. The observed data, which were used as the baseline scenario, mostly cover a 20 to 30-yr period starting from 1950.

The observed and simulated values were graphically displayed in order to determine which GCMs best fit the conditions at the different basins. Some of the models showed a better behaviour than others with regard to a given weather station. Thus, it was possible to define the 2 best graphical fits for both parameters at each station.

A transient GCM was also used to make comparisons and to identify climate change trends. Transient GCMs are considered more realistic since their results are a function of time. Transient scenarios were developed using monthly temperature and precipitation data for the 1951 to 1980 period with the transient model of the Geophysical Fluid Dynamics Laboratory (GFDL 1\%) (U.S. Country Studies Program 1994, IPCC 1995). The adjustment statistics for temperature provided by the model were added to the baseline (observed) data for each decade. The adjustment statistics for precipitation were multiplied by the baseline data (IPCC 1992). 

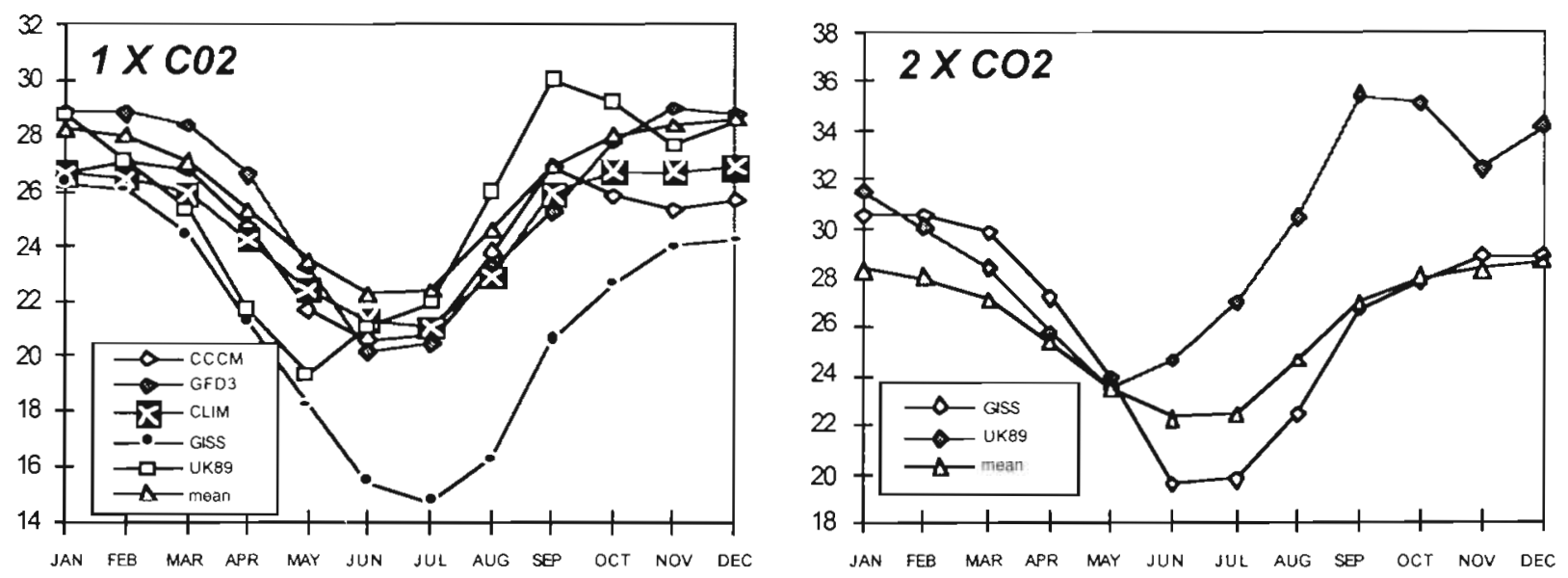

Fig. 3. Comparison of observed temperature data $\left({ }^{\circ} \mathrm{C}\right.$ ) and $\mathrm{GCM}$ outputs for Roboré station (Plata Basin; Chiquitos province, Santa Cruz department; $18^{\circ} 20^{\prime} \mathrm{S}, 59^{\circ} 46^{\prime} \mathrm{W}$, altitude $300 \mathrm{~m}$ )
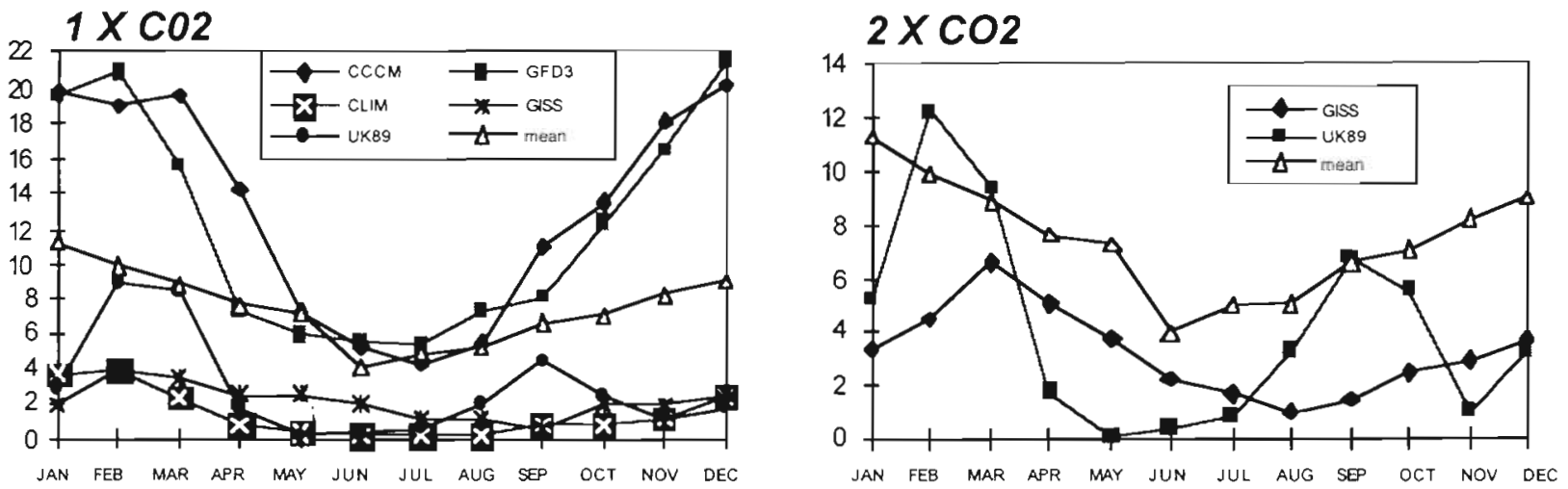

Fig. 4. Comparison of observed precipitation data $\left(\mathrm{mm} \mathrm{d}^{-1}\right.$ ) and GCM outputs for Copacabana station (Altiplano Basin; Manco Kapac province, $\mathrm{La} \mathrm{Paz}$ department; $16^{\circ} 10^{\prime} \mathrm{S}, 69^{\circ} 05^{\prime} \mathrm{W}$, altitude $3815 \mathrm{~m}$ )

Finally, incremental scenarios were also created. These scenarios provide a wide range of potential local climate changes and help to identify sensitivities to variations in temperature and precipitation. An increase in temperature $\left(+2^{\circ} \mathrm{C}\right)$ was combined with $\pm 10 \%$ changes in precipitation.

\section{RESULTS}

Fig. 3 displays, as an example, the graphic comparison of temperature observed data and GCM outputs for a weather station located in the eastern part of the country, both under the $1 \times \mathrm{CO}_{2}$ and $2 \times \mathrm{CO}_{2}$ scenarios.

Fig. 4 displays the comparison between observed and simulated mean monthly precipitation values at Copacabana station, located in the Altiplano region.

Table 1 displays, as an example, the differences in average temperature and precipitation values be- tween the $1 \times \mathrm{CO}_{2}$ and $2 \times \mathrm{CO}_{2}$ scenarios for the 3 basins studied, according to UK89 and GISS model outputs. The temperature values correspond to the absolute difference $\left(2 \times \mathrm{CO}_{2}-1 \times \mathrm{CO}_{2}\right)$ while precipitation values represent the $2 \times \mathrm{CO}_{2}$ to $1 \times \mathrm{CO}_{2}$ ratio.

An example of transient scenario results is presented in Fig. 5, which displays the temperature values under the baseline and climate change scenarios for a station within the Plata Basin.

A synthesis of average results under transient scenarios for each of the 3 basins is displayed in Table 2 . Temperature and precipitation variations under transient scenarios are presented by decades. Values for the fourth, seventh and tenth decades starting in 1970 are shown.

As mentioned earlier, incremental scenarios with a $2{ }^{\circ} \mathrm{C}$ increase in temperature combined with $\pm 10 \%$ changes in precipitation were also created for the 28 selected weather stations 
Table 1. Variation in temperature and precipitation averages between the $2 \times \mathrm{CO}_{2}$ and the current $\left(1 \times \mathrm{CO}_{2}\right)$ scenarios

\begin{tabular}{|c|c|c|c|c|c|c|c|c|c|c|c|c|c|}
\hline & Jan & Feb & Mar & Apr & May & Jun & Jul & Aug & Sep & Oct & Nov & Dec & Annual \\
\hline \multicolumn{14}{|c|}{ (a) Data generated with UK89 for Amazon Basin } \\
\hline Temp $\left(\Delta^{\circ} \mathrm{C}\right)$ & 0.82 & 0.80 & 0.15 & 1.04 & 1.46 & 2.48 & 3.46 & 3.12 & 3.75 & 4.78 & 3.20 & 2.00 & 2.25 \\
\hline Prec. ratio & 2.46 & 2.42 & 2.56 & 4.11 & 8.39 & 16.9 & 20.0 & 20.2 & 2.96 & 1.07 & 1.60 & 2.69 & 7.13 \\
\hline \multicolumn{14}{|c|}{ (b) Data generated with UK89 for Plata Basin } \\
\hline Temp. $\left(\Delta^{\circ} \mathrm{C}\right)$ & 2.73 & 2.93 & 2.95 & 3.53 & 3.73 & 3.07 & 4.30 & 4.31 & 4.83 & 4.44 & 2.81 & 2.79 & 3.53 \\
\hline Prec ratio & 0.84 & 1.21 & 1.28 & 1.52 & 1.11 & 16.9 & 0.79 & 20.2 & 0.92 & 0.85 & 1.42 & 1.16 & 4.01 \\
\hline \multicolumn{14}{|c|}{ (c) Data generated with UK89 for Altiplano Basin } \\
\hline Temp. $\left(\Delta^{\circ} \mathrm{C}\right)$ & 5.55 & 5.88 & 6.00 & 5.45 & 5.83 & 6.40 & 7.18 & 6.48 & 6.28 & 5.98 & 5.08 & 5.28 & 5.94 \\
\hline Prec. ratio & 1.47 & 1.41 & 1.22 & 1.35 & 1.00 & 16.9 & 1.13 & 20.2 & 1.60 & 1.78 & 0.97 & 1.51 & 4.21 \\
\hline \multicolumn{14}{|c|}{ (d) Data generated with GISS for Amazon Basin } \\
\hline Temp. $\left(\Delta^{\circ} \mathrm{C}\right)$ & 3.48 & 3.8 & 4.23 & 4.24 & 4.30 & 3.77 & 4.86 & 5.48 & 4.98 & 4.03 & 4.14 & 3.84 & 4.26 \\
\hline Prec. ratio & 1.22 & 1.27 & 1.38 & 1.58 & 1.69 & 1.08 & 4.42 & 1.28 & 1.13 & 1.60 & 1.19 & 1.44 & 1.61 \\
\hline \multicolumn{14}{|c|}{ (e) Data generated with GISS for Plata Basin } \\
\hline Temp. $\left(\Delta^{\circ} \mathrm{C}\right)$ & 4.18 & 4.44 & 5.29 & 5.65 & 5.46 & 3.96 & 5.02 & 5.97 & 5.91 & 5.10 & 4.77 & 4.61 & 5.03 \\
\hline Prec. ratio & 1.48 & 0.95 & 3.22 & 1.80 & 1.33 & 0.90 & 2.84 & 0.84 & 1.00 & 1.95 & 1.34 & 1.47 & 1.59 \\
\hline \multicolumn{14}{|c|}{ (f) Data generated with GISS for Altiplano Basin } \\
\hline Temp. $\left(\triangle^{\circ} \mathrm{C}\right)$ & 3.55 & 4.48 & 4.18 & 3.55 & 4.33 & 4.73 & 5.83 & 6.50 & 5.73 & 5.28 & 4.45 & 4.40 & 4.74 \\
\hline Prec. ratio & 2.26 & 1.42 & 2.07 & 2.13 & 1.44 & 0.99 & 1.43 & 0.88 & 3.67 & 1.85 & 2.33 & 1.88 & 1.86 \\
\hline
\end{tabular}

Table 2. Variation in temperature and precipitation averages under GFDL $1 \%$ transient scenarios using monthly weather data from the 1951 to 1980 period for each of the 3 basins

\begin{tabular}{|c|c|c|c|c|c|c|c|c|c|c|c|c|c|}
\hline Decade & Jan & Feb & Mar & Apr & May & Jun & Jul & Aug & Sep & Oct & Nov & Dec & Annual \\
\hline \multicolumn{14}{|c|}{ (a) Amazon Basin } \\
\hline Temp. $\left(\Delta^{\circ} \mathrm{C}\right)$ & 0.25 & 0.84 & 0.39 & 0.93 & 0.76 & 1.99 & 0.37 & 0.78 & 0.19 & 1.54 & 2.03 & 1.26 & 0.90 \\
\hline Prec, ratio & 1.26 & 1.64 & 1.15 & 1.15 & 1.06 & 0.73 & 0.99 & 1.22 & 0.78 & 0.87 & 0.91 & 1.20 & 1.08 \\
\hline \multicolumn{14}{|l|}{7 th $(2030)$} \\
\hline Temp. $\left(\Delta^{\circ} \mathrm{C}\right)$ & 0.91 & 1.46 & 1.39 & 2.00 & 2.07 & 2.04 & 1.66 & 2.46 & 1.49 & 2.29 & 2.89 & 2.20 & 1.90 \\
\hline Prec ratio & 1.33 & 1.06 & 1.02 & 1.12 & 1.19 & 0.70 & 0.99 & 1.16 & 0.75 & 0.90 & 0.85 & 1.33 & 1.04 \\
\hline \multicolumn{14}{|l|}{ 10th $(2070)$} \\
\hline Temp. $\left(\Delta^{\circ} \mathrm{C}\right)$ & 1.93 & 2.69 & 2.69 & 3.31 & 2.58 & 3.63 & 2.73 & 3.49 & 2.16 & 3.62 & 4.12 & 3.15 & 3.01 \\
\hline Prec ratio & 1.20 & 1.28 & 0.97 & 1.09 & 1.07 & 0.93 & 1.08 & 1.11 & 0.78 & 0.73 & 1.00 & 1.46 & 1.06 \\
\hline \multicolumn{14}{|l|}{$\begin{array}{l}\text { (b) Plata Basin } \\
\text { 4th }(2000)\end{array}$} \\
\hline Temp. $\left(\Delta^{\circ} \mathrm{C}\right)$ & 0.44 & 0.40 & 1.41 & 1.73 & 1.73 & 1.41 & 0.07 & 0.40 & 0.63 & 1.87 & 2.13 & 1.47 & 1.14 \\
\hline Prec ratio & 0.94 & 2.59 & 0.94 & 1.44 & 0.77 & 1.07 & 0.92 & 1.28 & 0.79 & 0.98 & 0.84 & 0.92 & 1.12 \\
\hline \multicolumn{14}{|l|}{7 th $(2030)$} \\
\hline Temp. $\left(\Delta^{\circ} \mathrm{C}\right)$ & 1.74 & 1.84 & 2.45 & 1.98 & 2.97 & 2.32 & 2.23 & 3.15 & 2.19 & 2.48 & 2.71 & 2.15 & 2.35 \\
\hline Prec. ratio & 1.19 & 1.61 & 1.23 & 0.94 & 1.25 & 1.02 & 0.73 & 1.06 & 0.87 & 1.03 & 1.08 & 1.21 & 1.10 \\
\hline \multicolumn{14}{|l|}{ 10th $(2070)$} \\
\hline Temp. $\left(\Delta^{\circ} \mathrm{C}\right)$ & 2.47 & 2.89 & 3.91 & 3.57 & 3.53 & 3.20 & 3.39 & 3.59 & 2.88 & 4.62 & 3.78 & 3.74 & 3.46 \\
\hline Prec. ratio & 1.46 & 3.25 & 1.12 & 1.59 & 0.88 & 1.15 & 1.16 & 1.42 & 0.87 & 0.89 & 0.96 & 1.01 & 1.31 \\
\hline \multicolumn{14}{|c|}{ (c) Altiplano Basin } \\
\hline \multicolumn{14}{|l|}{4 th $(2000)$} \\
\hline Temp. $\left(\Delta^{\circ} \mathrm{C}\right)$ & 0.81 & 1.64 & 1.04 & 0.91 & 0.73 & 0.84 & 0.89 & 1.58 & 0.86 & 1.26 & 2.32 & 1.15 & 1.17 \\
\hline Prec. ratio & 1.30 & 1.43 & 0.87 & 0.89 & 0.81 & 1.00 & 0.84 & 1.43 & 0.93 & 1.01 & 1.30 & 1.22 & 1.09 \\
\hline \multicolumn{14}{|c|}{7 th $(2030)$} \\
\hline Temp. $\left(\Delta^{\circ} \mathrm{C}\right)$ & 1.99 & 1.99 & 1.99 & 2.26 & 1.94 & 1.77 & 2.20 & 3.42 & 1.83 & 2.50 & 2.83 & 2.32 & 2.25 \\
\hline Prec. ratio & 1.19 & 1.51 & 0.80 & 0.86 & 0.90 & 1.04 & 0.92 & 1.60 & 1.08 & 1.03 & 1.15 & 1.18 & 1.10 \\
\hline \multicolumn{14}{|l|}{ 10th $(2070)$} \\
\hline Temp. $\left(\Delta^{\circ} \mathrm{C}\right)$ & 3.29 & 3.44 & 3.38 & 3.59 & 3.42 & 3.74 & 3.38 & 4.40 & 2.74 & 3.84 & 4.09 & 4.51 & 3.65 \\
\hline Prec ratio & 1.33 & 1.60 & 0.85 & 1.19 & 0.88 & 0.98 & 0.95 & 1.66 & 0.95 & 1.09 & 1.31 & 1.50 & 1.19 \\
\hline
\end{tabular}



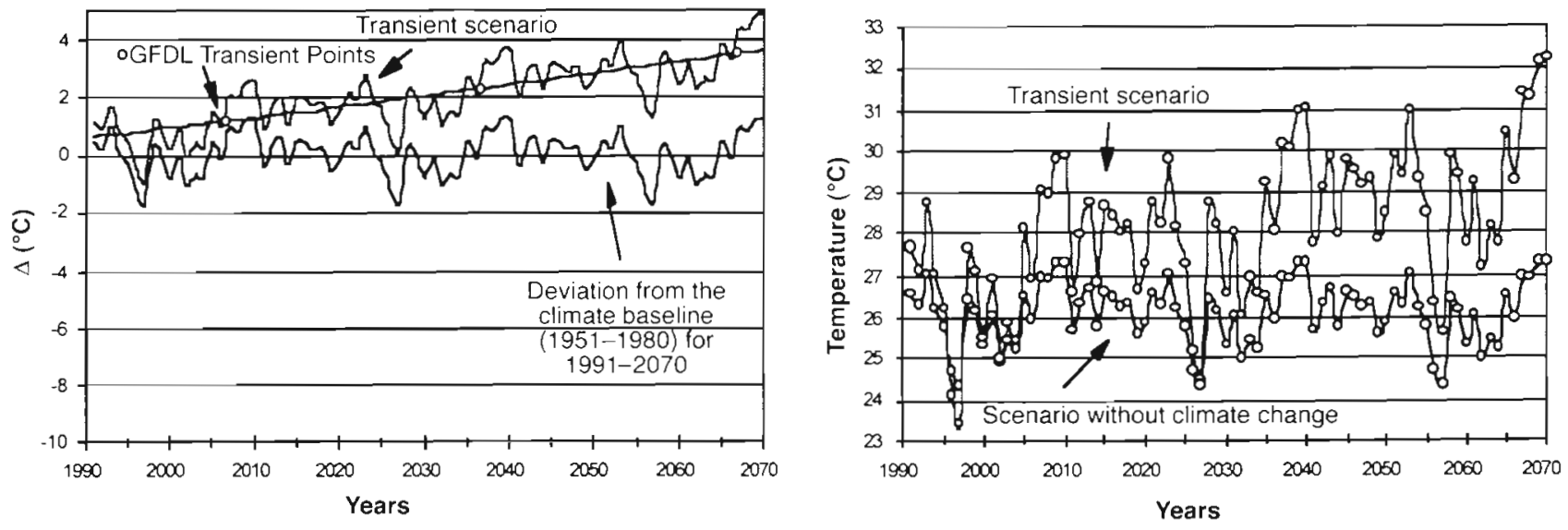

Fig. 5. Temperature values under the baseline and climate change scenarios developed with the GFDL $1 \%$ (transient model) for Roboré station (Plata Basin; Santa Cruz department; $18^{\circ} 20^{\prime} \mathrm{S}, 59^{\circ} 46^{\prime} \mathrm{W}$, altitude $300 \mathrm{~m}$ )

Study results indicate that the GCMs which do better in replicating local climate are different for each basin, given their different climatic conditions. The most reasonable approach is provided by GISS and UK89 for the Amazon Basin; UK89, GFDL R-30 and CCCM for the Plata Basin; and GISS and UK89 for the Altiplano Basin. However, in order to follow the same methodalogical process for the country as recommended by the U.S. Country Studies Program (1994), only UK89 and GISS were selected for the development of climate change scenarios for vulnerability and adaptation studies in Bolivia.

\section{DISCUSSION}

Results from the assessment of those GCMs providing a more accurate estimate of current climate data and simulating a similar trend under $1 \times \mathrm{CO}_{2}$ conditions were the basis for defining the scenarios which could result from future climate changes due to a doubling in atmospheric carbon dioxide $\left(2 \times \mathrm{CO}_{2}\right)$. The projections made may be considered as trends or possible scenarios, but should not be taken as predictions, since GCM outputs still carry several limitations.

Fitting of observed and simulated data displayed graphically was good with regard to temperature but not for precipitation. The best fitting was found with GISS and UK89 model outputs. The scenario developed with GISS is characterized by an increase in temperature and slight decrease in precipitation, while the UK89 scenario describes both temperature and precipitation increases. These are general results, and do not apply in the case of some of the stations.

In the Amazon Basin, the projected trend under doubled $\mathrm{CO}_{2}$ consists of an increase in temperature and a decrease in precipitation. In the Plata Basin the temperature increase projected by GISS is higher than that estimated by UK89. However, both models simulate a precipitation decrease for the typically rainy months and a slight increase for the driest months. Finally, the trend under a $2 \times \mathrm{CO}_{2}$ scenario in the Altiplano Basin indicates a temperature increase, as estimated by both GISS and UK89. A general precipitation decrease is projected, except in certain months (particularly January and February) for which a considerable increase is simulated.

GCM outputs simulate an extremely high increase in precipitation during the usually dry months (June, July and August). This would in turn induce a significant bias in the annual mean values.

A temperature increase is projected for all 3 basins by the transient model (GFDL $1 \%$ ). However, the simulated precipitation may vary depending on the basin and on the location of the station studied.

Caution should be exercised when considering the results presented in the tables above, where the average trends provided by each model as well as the estimated potential annual values of temperature and precipitation increase or decrease are shown. It should be taken into account that the river basins under study are very large and have a variety of climate conditions due to the altitude differences among mountains and plains.

\section{CONCLUSIONS}

It was observed that, under the $1 \times \mathrm{CO}_{2}$ scenario, the UK89 and GISS models best estimated the actual data, as determined by graphical comparisons. However, these models provided different temperature and precipitation projections under a $2 \times \mathrm{CO}_{2}$ condition. 
The use of average values for the different river basins of the country may lead to wrong conclusions given the variety of climates that are present in Bolivia as a result of considerable variations in altitude.

In general terms, a future climate change scenario under $2 \times \mathrm{CO}_{2}$ conditions would imply a temperature increase of 1 to $4{ }^{\circ} \mathrm{C}$, and either a $15 \%$ decrease or $20 \%$ increase in precipitation, depending on the GCM being used.

Mean variations estimated under transient scenarios indicate a temperature increase of about $3^{\circ} \mathrm{C}$ for all 3 basins under study, and either increases or decreases in precipitation ranging between 5 and $30 \%$.

\section{LITERATURE CITED}

IPCC (Intergovernmental Panel on Climate Change)(1992) Cambio climático: evaluación científica del IPCC. Organización Meteorológica Mundial/Programa de las Naciones Unidas para el Medio Ambiente, Madrid

IPCC (Intergovernmental Panel on Climate Change) (1995) Directrices técnicas del IPCC para evaluar impactos del cambio climático y estrategias de adaptación. Organización Meteorológica Mundial/Programa de las Naciones Unidas para el Medio Ambiente, Ginebra

SENAMHI (Servicio Nacional de Meteorología e Hidrología) (1995) Planillas de información climatológica de Bolivia. SENAMHI, La Paz

U.S. Country Studies Program (1994) Guidance for vulnerability and adaptation assessments. U.S. Country Studies Program, Washington, DC 